\title{
Пошук та розвиток спортивного таланту: ретроспективний та сучасний аналіз
}

\author{
Оксана Шинкарук
}

Національний університет фізичного виховання і спорту України, Київ, Україна

Анотація. Насичений спортивний календар змагань, щільність спортивних результатів, розширення географії країн-фріналістів змагань висувають високі вимоги до підготовки спорстменів у різних видах спорту та постійного пошуку талановитої молоді, формування дієвої системи відбору. Мета. За даними аналізу та систематизації спеціальної наукової літератури і власних багаторічних досліджень розкрити актуальність пошуку талановитої молоді у спорті та формування і впровадження багатоступеневої системи відбору й орієнтації підготовки спортсменів. Методи. Аналіз та узагальнення даних науковометодичної літератури та мережі Інтернет, відеоаналіз змагальної діяльності, анкетування, педагогічне спостереження, тестування, метод експертних оцінок, методи математичної статистики. Результати. Досліджено різні трактування розуміння природи таланту. Визначено два підходи до ідентифрікації таланту: 1) грунтується на позиції, що «природний талант» надійно детермінується вродженими генетично переданими характеристиками і має вирішальне значення в досягненні досконалості в певній сфері; 2) специфічні таланти виникають на основі успадкованих здібностей у результаті впливу навколишнього середовища. Спірним питанням є ступінь і значущість впливу успадкованого фактора на майбутню актуалізацію таланту та середовища і виховання під час втілення виняткових здібностей і навичок. Пошук та розвиток таланту спортсмена повинен здійснюватися в процесі багаторічно підготовки систематично, багатоступінчасто, що пов'язано з високою надійністю прогнозів у дитячому віці відповідно до спортивних досягнень цих спортсменів у старшому віці. На етапах підготовки змінюється значущість різних властивостей і особливостей морфологічного і фуннкціонального стану спортсмена, що визначають його обдарованість і перспективність до спортивного вдосконалення. Система тестування повинна відповідати завданням тренування на певному етапі багаторічної підготовки спортсменів; використання комплексного підходу в процесі відбору та орієнтації підготовки спортсменів з урахуванням різних сторін оцінювання їх можливостей дозволяє підвищити об'єктивність рекомендацій до їх перспективності. Спортивний талант - комплекс індивідуальних властивостей, ряд яких проявляється гетерохронно залежно від віку і спортивного стажу. Індивідуальні можливості спортивних досягнень і особистісні установки на їх реалізацію динамічні, змінюються як через природні особливості індивідуального розвитку, так і під впливом середовища. Ідентифрікацію та розвиток спортивного таланту і спортивну орієнтацію необхідно здійснювати як поетапно поновлюваний процес.

Ключові слова: спорт, талант, пошук, ідентифікація, підходи, прогноз, відбір, орієнтація.

\section{Oksana Shynkaruk}

\section{SEARCH AND DEVELOPMENT OF SPORTS TALENT: RETROSPECTIVE AND MODERN ANALYSIS}

Abstract. The intensive calendar of competitions, the density of sports results, the expansion of the geography of the countries-finalists of the competition make high demands on athlete preparation in various sports events and the constant search for talented youth, the formation of an effective selection system. Objective. According to the analysis and systematization of specia scientific literature and own long-term researches to reveal urgency of search for talented youth in sport and formation and introduction of multilevel system of selection and orientation of athlete preparation. Methods. Analysis and generalization of data of scientific and methodical literature and the Internet, video analysis of competitive activities, questionnaires, pedagogical observation, testing, method of expert evaluations, methods of mathematical statistics. Results. Different interpretations of the nature of talent understanding have been studied. Two approaches to the identification of talent have been determined: 1) the one based on the position that "natural talent" is reliably determined by innate genetically transmitted characteristics and is crucial for achieving excellence in a particular field; 2) specific talents arise on the basis of inherited abilities as a result of environmental influences. The controversial issue is the degree and significance of the inherited factor impact on the future actualization of talent and environment and education during the implementation of exceptional abilities and skills. The search for and development of the athlete's

Shynkaruk 0. Search and development of sports talent: retrospective and modern analysis. Theory and Methods of Physical education and sports. 2020; 2: 47-58 DOI: 10.32652/tmfvs.2020.2.47-58
Шинкарук О. Пошук та розвиток спортивного таланту: ретроспективний та сучасний аналіз. Теорія і методика фізичного виховання і спорту. 2020; 2: 47-58 DOI: 10.32652/tmfvs.2020.2.47-58
Вступ. Проблема пошуку талановитих дітей для занять спортом у сучасних умовах його розвитку, глобалізації та популяризації набуває особливої значущості. Насичення спортивного календаря змагань, щільність спортивних результатів, розширення географії країн-фріналістів змагань висувають високі вимоги до підготовки спортсменів у різних видах спорту, перед тренерами та науковцями постає завдання постійного пошуку талановитої молоді, формування дієвої системи відбору на всіх етапах багаторічної підготовки та раціональної орієнтації тренувального процесу [20, 23].

Ефективність такого пошуку ускладнюється тим, що на початкових етапах багаторічної підготовки спортивний результат юних спортсменів не може розглядатися як критерій перспективності. Крім того, для ряду інших інсрормативних показників, які застосовують у процесі відбору дорослих спортсменів, характерна вікова динаміка $[13,23]$.

Зацікавленість питаннями пошуку перспективних дітей до занять спортом виникла в останні десятиліття на різних континентах у багатьох країнах, привернула увагу до розробки системи пошуку та селекції відомих фахівців $[3,4]$.

Аналіз даних спеціальної літератури різних років дозволив ссрормулювати ряд загальних теоретикометодологічних положень проблеми. По-перше, відбір і орієнтацію підготовки спортсменів необхідно здійснювати у процесі багаторічного вдосконалення систематично, багатоступінчасто, оскільки надійність прогнозів, зроблених у дитячому віці, відносно спортивних досягнень цих спортсменів у старшому віці невисока. Подруге, об'єктивність висновку про перспективність та можливості спортсменів багато в чому залежить від комплексного підходу до оцінки стану різних систем організму, які забезпечують високу роботоздатність спортсменів в умовах змагальної діяльності 
talent should be carried out in the process of long-term training systematically, in several stages, which is associated with high reliability of predictions in childhood in accordance with the athletic achievements of these athletes in later years. At the stages of training, the significance of various capacities and features of the morphological and functional state of the athlete changes, which determine his talent and prospects for sports improvement. The testing system must meet the objectives of training at a certain stage of long-term athlete preparation; the use of complex approach in the process of selection and orientation of athlete preparation with account for the various aspects of assessing their capabilities allows to increase the objectivity of the recommendations with respect to their prospects. Sports talent is a complex of individual characteristics, a number of which are manifested heterochronously depending on age and sports experience. Individual opportunities for sports achievements and personal affirmsations to their realization are dynamic, changing both due to the natural features of individual development and under the influence of the environment. Identification and development of sports talent and sports orientation should be carried out as a progressively updated process

Keywords: sport, talent, search, identification, approaches, forecast, selection, orientation.

в обраному виді спорту або в окремій змагальній дисципліні. Це положення враховували в багатьох країнах, де наявна система відбору спортсменів. По-третє, комплексний підхід ґрунтується на врахуванні індивідуальних фрізичних, психологічних характеристик та технічних дій спортсмена, паспортного та біологічного віку, показників фрізичного стану і рухової активності на етапі, що передував моменту обстеження [3, 5, 9, 22, 29, 46, 47].

Спортивний талант знаходиться в центрі уваги спортивних аналітиків вчених вже давно. Традиційно ідентифрікація спортивної обдарованості і таланту була пов'язана з оптимальним для певного виду спорту поєднанням антропометричних показників, високим рівнем навченості і тренованості, високою мотивацією, наполегливістю і здатністю до змагальної боротьби [8, $12,43]$.

Основними напрямами вивчення спортивної обдарованості $€$ побудова ближніх і дальніх прогнозів. Ближні прогнози будуються на вивченні задатків і здібностей, в результаті яких можна дати рекомендації до доцільності вибору виду спорту для того або іншого підлітка. Дальні прогнози зумовлюються рівнем розвитку, темпами приросту і стабільністю основних якостей, що визначають зростання спортивної майстерності [23].

Здібності розглядають як індивідуальні особливості людини, від яких залежить успішність виконання ії діяльності. Їх слід розглядати і як складну структуру, що має спеціальні компоненти. Вони за своєю суттю $є$ поняттям динамічним, а їх розвиток відбувається в процесі діяльності.
Обдарованість визначають як поєднання здібностей, від яких залежить можливість досягнення більшого або меншого успіху в тій або іншій діяльності. Спортивну обдарованість розглядають як поєднання здібностей, що забезпечують високі досягнення у спорті, тоді як талант розглядають як природне дарування, вищий ступінь обдарованості [29].

у 1980 р. Гарднером [41] було створено класифрікацію талантів, до якої пізніше додалося ще кілька десятків видів обдарованості, це такі таланти: вербально-лінгвістичний цифровий; просторовий; фрізичний, пов'язаний 3 тілом: органами чуттів, фізичною підготовкою, гнучкістю тощо; емоційний (особистісний) криється в глибокій рефлексії; міжособистісний заснований на вмінні доносити до інших як особисті переживання, так і образи; навколишнього середовища властивий людям, як вміють гармонійно і продуктивно взаємодіяти з силами природи, розуміючи її закони; комбінований може поєднувати будь-які два або кілька талантів в одній людині.

Незважаючи на важливість і актуальність проблеми спортивного таланту, дослідження цього явища потребують систематизації та продовження пошуку.

Мета дослідження - за даними аналізу та систематизації спеціальної наукової літератури і власних багаторічних досліджень розкрити актуальність пошуку талановитої молоді у спорті та формування і впровадження багатоступеневої системи відбору й орієнтації підготовки спортсменів.

Матеріал і методи дослідження. У ході проведення дослідження було за- стосовано теоретичні та емпіричні методи

Теоретичні методи (теоретичний аналіз та узагальнення даних науковометодичної літератури та мережі IHтернет, систематизація) дозволили провести ретроспективний та сучасний аналіз питань пошуку та ідентифікації таланту, визначити існуючі підходи до відбору та орієнтації підготовки спортсменів у багаторічному процесі вдосконалення.

Емпіричні методи досліджень (аналіз протоколів змагальної діяльності, даних спортсменів, відеоаналіз, анкетування, педагогічне спостереження, тестування 3 використанням інструментальних методів - аналізу складу тіла, психодіагностики, біомеханічного тестування з використанням оптико-електронної системи «OptoJump», «Qualisys», програмного пакетного комплексу «Visual 3D», ергометрії, пульсометрії, газоаналізу, експеримент, метод експертних оцінок, методи математичної статистики) дозволили визначити особливості змагальної діяльності в гімнастиці, веслуванні, баскетболі, фехтуванні, виявити та систематизувати думки тренерів, спортсменів, батьків про критерії, тести, підходи в процесі відбору спортсменів, експериментально перевірити технологію відбору спорстменів, динаміку показників та визначити перспективність атлетів.

В експертному оцінюванні використовували метод переваги. Узгодженість думок експертів перевіряли за допомогою розрахунку коефріцієнта конкордації Кендалла. Для підтвердження коесріцієнта конкордації, що характеризує середній ступінь узгодженості думок експертів, перевіряли його значущість за критерієм

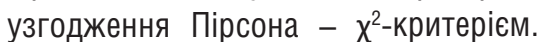
Статистичну обробку даних проводили за допомогою програмного пакета математичної статистики «Statistica 6.0» (StatSoft Inc., США, 1999) і редактора таблиць «Excel 2003» (Microsoft, США, 2003). Для обробки даних, отриманих у ході дослідження, використовували метод середніх величин, що включав розрахунок середнього значення, стандартного відхилення. Коефріцієнт варіації (V, \%) використову- 
вали для визначення однорідності вибірки [32] .

Дослідження проводили протягом 2007-2019 рр., в яких брали участь:

- у веслуванні на байдарках і каное - експертне оцінювання - 41 провідний тренер, опитування - 158 дітей, 299 батьків, педагогічний експеримент - 200 дітей 10-12 років, м. ІваноФранківськ;

- у художній гімнастиці - 50 спортсменок, які знаходяться на етапах початкової (20 осіб) та попередньої базової підготовки (30 осіб); опитування та експертне оцінювання - 46 тренерів та суддів з художньої гімнастики України різної кваліфрікації, м. Київ;

- у фехтуванні - проаналізовано 54 міжнародні змагання та 9 всеукраїнських змагань, виступи 1200 спортсменів, що входять до міжнародного рейтингу, 120 спортсменів України, що спеціалізуються у фехтуванні на різних видах зброї, експериемнт - 9 фехтувальників МС України та КМС, фехтувальники-початківці - 20 хлопчиків та дівчат, спеціалізація шпага, м. Київ;

- у баскетболі - аналіз змагальної діяльності спортсменів 8 провідних зарубіжних країн та України (по 125 осіб), експеримент - 52 баскетболісти (MCMK, MC, KMC, I розряд: національна збірна України (14), команди Суперліги “Будівельник" (13), Вищої ліги «Легпром» і «МНТУ»(25), м. Київ;

- у веслуванні академічному - експеримент - діяльність 38 спортсменів (MCMK, MC і KMC), опитування та експертна оцінка - 23 провідних тренери 3 веслування академічного.

Результати дослідження та їх обговорення. Розглядаючи проблему пошуку талантів, науковці не мають єдиного трактування розуміння природи таланту. В. Б. Іссурін, досліджуючи цю проблему, дає, на його думку, найбільш повне і чітке визначення таланту, запропоноване Howe et al. як «спеціальні здібності, які дозволяють комусь досягти досконалості в будь-якій діяльності в певній галузі». Для пояснення такого визначення розглянемо п'ять істотних властивостей таланTy $[8,45]$ :
1) у спадок передаються риси, які визначають його вроджені характеристики;

2) наявність індикаторів, які рано проявляються та дозволяють експертам визначити наявність таланту, проте в ході попереднього спостереження вони можуть бути неочевидними;

3) ранні ознаки майбутнього таланту, що дозволяють прогнозувати подальший успіх особистості в певній галузі;

4) відносно невелика частина оцінюваної субпопуляції, яку становлять талановиті люди;

5) реалізація таланту, зазвичай, тільки в певній галузі.

У своїх дослідженнях В. Б. Іссурін свідчить про загальне переконання, що значною складовою справжнього таланту є успадковані характеристики, які формують основу специфічної обдарованості або здатності до певної діяльності. Ці генетично зумовлені людські риси можуть бути обгрунтовано кваліфіковані як вроджені компоненти таланту [8]. Інші учені підкреслюють біологічну природу генетично переданих талантів і стверджують, що такі терміни, як «обдарованість» і «здібності» часто використовують для характеристики таланту на ранніх етапах його визнання [36, 38] .

Більшість досліджень проведено в галузі біології та педагогиці [45]. Це пов'язано з тим, що ранні прояви обдарованості дітей та таланти виявляються переважно батьками і вчителями, проте також можуть бути виявлені випадково. Звичайно, різні види діяльності дають різні можливості для виявлення талантів у різному віці. У будь-якому випадку ранні ознаки таланту активно використовуються для передбачення великих професійних успіхів у майбутньому.

Труднощі в проведенні досліджень та виявленні талантів пов'язані 3 невеликим відсотком талановитих дітей у звичайній популяції. Так, Carroll визначає рівень у $10 \%$ талановитих дітей 3 різних сфрер людської діяльності [33]. Він зазначає, що поява винятково обдарованої дитини $є$ унікальним випадком 3 вірогідністю близько 1 \%. Загальна логіка і людський досвід підтримують твердження про те, що та- лант - дуже специсрічне явище, яке застосовується тільки до конкретної сфери людської діяльності. Така специфічність може бути частково пояснена високою концентрацією вундеркіндів у сфрері застосування їхньої обдарованості, хоча нейрофрізіологічні передумови такої селективності не можуть бути виключені.

Цікавими є дослідження Gagné, який обґрунтував диференційовану модель обдарованості й таланту та припустив, що специфічні таланти в таких галузях, як математика, мистецтво, музика, наука тощо виникають на основі успадкованих здібностей у результаті впливу навколишнього середовища (сім'ї, школи, формальної та неформальної активності) [39].

Якщо припустити, що екстраординарні здібності особистості, принаймні частково, визначаються біологічним фроном, цілком ймовірно, що ці неврологічні і психосоматичні чинники можуть зумовити винятковий потенціал в одній сфері, але не в іншій. Одним 3 найбільш спірних і сумнівних питань, яке визанчає В. Б. Іссурін, $€$ ступінь і значущість впливу вродженого успадкованого фактора на майбутню актуалізацію таланту, а також вирішальна роль виховання під час втілення виняткових здібностей і навичок [8].

Загальна позиція, яка користується популярністю серед багатьох учених і аналітиків, полягає в тому, що «природний талант» надійно детермінується вродженими генетично переданими характеристиками і має першорядне і вирішальне значення в досягненні досконалості у певній ссрері. Така позиція ґрунтується на даних, зібраних і згрупованих за трьома напрямами, а саме: 1) дуже ранні прояви екстраординарних здібностей і навичок; 2) досягнення видатної майстерності в певній галузі за відсутності навчання і допомоги ззовні; 3) наявність біологічних ознак і показників, що впливають на досягнення визначного результату.

Огляд наукової літератури показує велику кількість публікацій, в яких наявність природного таланту ставиться під сумнів або навіть не визнається. Наприклад, дослідження 
Manturzewska біографій 165 професійних польських музикантів, Sloane i Sosniak - біографрій видатних художників, a Gustin - математиків пояснюють здібності найуспішніших особистостей батьківською підтримкою і раннім початком усвідомленої практики. Автори порівнювали динаміку показників майстерності більш успішних респондентів 3 менш успішними, які також досягли високого професійного рівня [42, 49, 52].

Дослідження, проведені Sloboda et al., свідчать, що успішні молоді музиканти не показали переваги в набутт профресійних навичок порівняно 3 іншими дітьми за однакових затрат часу на практику [53]. Simonton стверджує, що видатні композитори витратили 10 років і більше для досягнення високого рівня у своїй професії [51].

Ще один аргумент стосується існування сенситивних періодів, в які людина виявляє підвищені здатності реагувати на будь-яку нову інформацію, що дозволяє полегшити й успішніше набувати і розвивати нові навички та здібності. Можна припустити, що належне використання сенситивних періодів підсилює вплив навколишнього середовища, але не вроджених фракторів.

Ще один чинник - недостатня точність прогнозування та ідентифрікації таланту. Tesch-Romer зазначає, що ряд важливих обставин, зазвичай, не враховується: вік раннього виявлення, обсяг, зміст і якість початкової практики, зовнішня мотивація та підтримка сім'ї. Він підкреслює, що наведені фактори зазвичай оцінюються необ'єктивно, а на основі ретроспективних звітів батьків або членів сім'ї [55]. Крім того, часто ймовірність передбаченого успіху дуже низька, тому що успіх на найвищому рівні трапляється рідко і залежить від багатьох непередбачуваних обставин.

Точність різних прогностичних програм неодноразово оцінювалася серйозними спортивними аналітиками. Taк, Lidor 3 співавт. вивчали можливість застосування широко використовуваних фрізіологічних і антропометричних показників як прогностичних факторів майбутньої спортивної майстерності [48]. Грунтуючись на даних численних досліджень, вони не знайшли переконливих доказів наявності ранньої дисреренціації між дуже талановитими і менш талановитими молодими людьми. У літературі, присвяченій спортивній науці, є рідкісні приклади лонгітудинальних досліджень, в яких порівнювалися дан спортсменів світового класу 3 даними висококваліфрікованих спортсменів, але нижчого рівня.

Ericsson et al. запропонував «Tеорію десятирічної усвідомленої практики», яка базувалася на даних, зібраних серед студентів музичної академії та високопрофресійних музикантів а згодом серед висококваліфікованих професійних математиків і спортсменів високого рівня, в основному шахістів і тенісистів. Відповідно до цієї теорії, досягнення найвищого рівня майстерності вимагає 10000 годин або 10 років усвідомленої практики в обраній галузі. Усвідомлена практика була визначена як високоякісна висококонцентрована практична активність, яка, за своєю суттю, не завжди приємна виконавцю; ця практична діяльність повинна ставати з часом все більш складною, а головною її метою має стати підвищення рівня майстерності [35].

Засновник цієї теорії професор Ericsson підкреслює роль мотиваційного чинника, який впливає на ефективність усвідомленої практики у найбільш успішних особистостей. Він стверджує, що звичні види діяльності не передбачають прикладення будьяких зусиль, що не стимулює прогрес у досягненні експертного рівня майстерності [34]. На відміну від цього, особистості, високомотивовані на виконання, контроль і моніторинг програм своєї діяльності на більш високому рівні, створюють імпульс для більш вираженого підвищення рівня розвитку навичок і здібностей, ніж менш успішні індивідууми. Відповідно до цього припущення саме робота вимагає зусиль на шляху до вищого рівня майстерності, а не вроджен риси визначають досконалість, тобто талант.

Додатковий внесок в теорію усвідомленої практики зробив Simonton, який визнав багатоплановий характер таланту, складовими якого $є$ фізіологічні, психологічні та фрізичні компоненти. Однак у своїй концептуальній моделі він підкреслює роль фракторів навколишнього середовища, виділяючи важливість і специфічність детермінант, що визначають досягнення рівня майстерності й саме майстерність. Відповідно до його концепції, детермінанти майстерності фрормують основу здібностей особистості в умовах змагальності, тоді як детермінанти набуття майстерності впливають на успішність процесу навчання. Як стверджував автор, взаємодія цих фракторів створює мультиплікативний ефект, при якому вплив навколишнього середовища перевершує внесок спадковості [51].

«Правило 10 років» стало популярним i широко обговорюваним серед фрахівців в сфері підготовки спортсменів.

У спортивній науці фахівці визначають відбір як «безперервний процес виявлення талановитих спортсменів на різних етапах тренувальної програми» [48]. Вони стверджують, що «розвиток талантів має на увазі, що спортсмени/гравці постійно забезпечені відповідними умовами навчання / практики з метою заохочення і реалізації свого потенціалу в конкретному виді спорту» [48]. Подальші дослідження та практична інтерпретація ідентифрікації і розвитку таланту привели до розробки ряду програм для раннього виявлення потенційно талановитих спортсменів і їх раціональної, есрективної і науково обґрунтованої підготовки [28, 37, 44].

На сьогодні накопичено науковий матеріал, що дозволяє судити про різні сторони спортивних здібностей, про форми організації та методику відбору, про методологічні підходи до вивчення питань відбору та орієнтації $[1$, 4, 6, 7, 21, 31, 40]. Перед спортсменами і тренерами стоїть завдання - досягти найвищих результатів за рахунок прояву природних задатків і застосування сучасних методів їх розвитку. Саме це мають на увазі, коли говорять про підвищення спортивних досягнень за допомогою відбору спортивних талантів. Тому мета спортивного відбору не стільки 
у встановленні придатності до даного виду спорту, скільки у виявленні потенційних можливостей спортсмена і визначенні шляхів розкриття його таланту в процесі підготовки. Визначення схильності до різних спортивних дисциплін (спортивна орієнтація) будується на основі визначення задатків, що відповідають вимогам певного виду спорту.

Ряд досліджень, що стосуються безпосередньо відбору спортсменів, базується на серії послідовних короткострокових прогнозів [4, 15, 17], на які допускається розподілити час одного довгострокового прогнозу. Такий підхід видається більш надійним, ніж його довгостроковий прогноз з використанням методів генетики, і спирається на стабільність спадково обумовлених ознак. Короткострокові, від етапу до етапу, прогнози базуються на даних про динаміку вікового розвитку фрізичних, функціональних і інших якостей і ознак з урахуванням усіх їх відхилень від норми внаслідок тренування. У зв'язку з цим багато фахівців, у тому числі генетиків [11, $16,40]$, рекомендують як основу використовувати відомі в спортивній практиці педагогічні, медико-біологічні і психологічні методи дослідження [5, 19]. Соціальна необхідність відбору сприяла глибокому вивченню питань, пов'язаних зі спортивною орієнтацією і селекцією спортсменів. Особливу увагу в спеціальній літературі приділено принципам і завданням відбору $[21,23]$. Проте думки фрахівців суперечливі і недостатньо узгоджені.

Зіставляючи думки фахівців, які вивчали окремі проблеми дитячоюнацького спорту, можна зробити висновок, що відбір здібних спортсменів у процесі багаторічної підготовки здійснюється поступово. У своїх дослідженнях В. А. Запорожанов [56] і К. П. Сахновський [14] виділяють три етапи. На першому етапі під час проведення відбору виявляють перспективні можливості спортсмена і доцільність занять обраним видом спорту, використовують анатомо-морфологічні, деякі фрізіологічні і психофізіологічні показники. Відбір на другому етапі спрямований на виявлення у спортсменів потенцій- них здібностей до досягнення високих спортивних результатів на наступних етапах підготовки. Тут поряд 3 показниками, рекомендованими для попереднього ступеня відбору, враховують соціально-психологічні та педагогічні показники, що дозволяють простежити темпи зростання спортивної майстерності, ступінь освоєння техніки, здатність стабільно демонструвати спортивну майстерність. У циклічних видах спорту особливу увагу приділяють фрізіологічним показникам $[25,50]$. На третьому етапі відбору визначають можливості спортсменів досягати результатів міжнародного класу і демонструвати відповідні показники в умовах жорсткої конкуренції, включаючи міжнародні змагання. Відбір здійснюється переважно за допомогою педагогічних і психологічних показників, що дозволяють виявити рівень спортивної майстерності та стійкість спортсменів до збиваючих фракторів фрізичного і психічного плану.

Щодо організації відбору, існують і інші точки зору. Так, в роботі В. М. Волкова та В. П. Філіна [5] мова йде про доцільність виділяти чотири етапи: попереднього відбору; поглибленої перевірки спортсменів відповідності вимогам обраного виду спорту; спортивної орієнтації; відбору в збірні команди. Р. Є. Мотилянська і М. А. Налбандян [10] виділяли чотири етапи: попереднього (первинного) відбору дітей і підлітків; поглибленої перевірки відповідності відібраного контингенту вимогам, що висувають до успішної спеціалізації в обраному виді спорту (етап вторинного відбору); спортивної орієнтації; відбору в збірні команди. Думки фахівців у цьому питанні неоднозначні. Так, Н. Ж. Булгакова [4] виділяє три основні етапи, характеризуючи їх таким чином: вибір виду спорту з урахуванням його вимог; виявлення здібностей до прогресу в процесі навчання і тренування; відбір найбільш талановитих спортсменів, здатних показувати результати міжнародного класу. Автор відзначає відповідність цих етапів різновидам відбору: спортивної орієнтації, комплектуванню команди, спортивної селекції. У той самий час
М. С. Бриль [3] розглядає проблему відбору як з організаційних, так і з методологічних позицій.

Думки різних учених збігаються тільки в тому, що відбір необхідно здійснювати багатоступінчасто, використовуючи на кожному етапі підготовки різні комплекси показників. У цілому більшість фрахівців вважають, що весь процес відбору доцільно розділити на три етапи, пов'язуючи цей процес 3 віком, кваліфікацією і найбільш сприятливими для розвитку фізичних якостей сенситивними періодами розвитку організму спортсмена $[1,5]$. Таким чином, кожному етапу спортивного відбору відповідає порівняно однорідний за рівнем кваліфрікації контингент спортсменів, певні часові межі (терміни) етапу відбору, а також специфрічна сукупність вирішуваних завдань і використовуваних для цього коштів, методів, показників, вибір яких здійснюється 3 урахуванням особливостей конкретного виду спорту. Можна зробити висновок, що основним змістом усіх етапів спортивного відбору є прогнозування спортивної обдарованості (перспективних можливостей) спортсмена за допомогою спеціальних тестових процедур і об'єктивних кількісних показників.

Багатоступінчастий підхід до організації відбору доцільний у зв'язку 3 тим, що надійність прогнозів, зроблених в ранньому дитячому віці, по відношенню до спортивних досягнень цих самих спортсменів у старшому віці дуже низька. Особливу увагу звертає на себе та обставина, що чим старшим стає спортсмен і чим коротший часовий інтервал, на який поширюється прогноз, тим вища надійність висновків про його перспективність.

Об'єктивність оцінки потенційних можливостей спортсмена й успіх спортивного відбору в цілому багато в чому залежать від правильного вибору критеріїв, окремих показників, умов їх реєстрації та об'єктивності інформації про спортсмена. Оскільки відбір спортсменів здійснюється 3 позиції вимог конкретних видів спорту, програми тестування повинні мати специфрічний характер. 
Ряд досліджень присвячено виявленню прогностичної значущості різних показників [7, 50, 56]. Дослідники прагнуть визначити прогностично значущі анатомо-морфологічні, психологічні та інші ознаки. 3 цією метою вивчаються генетично обумовлені особливості будови форм і частин тіла станом яких і виявляється схильність до певного виду. Багато досліджень базується на функціональних і інших можливостях спортсменів, визначаючи їх прогностичність на основі кореляції зі спортивним результатом. У різних видах спорту успіх обумовлений рівнем розвитку специфічних якостей, це привело до твердження частини фрахівців, що прогностичність повинна визначатися саме за цими ознаками. Проте в тому, на що орієнтуватися - на головну ознаку або на їх комплекс, думки фахівців розходяться. Більшість віддає перевагу комплексному оцінюванню $[23,56]$, тоді як деякі автори виділяють одну-дві найбільш інформативні ознаки [1].

Особлива зацікавленість більшості фахівців до визначення прогностичності різних ознак свідчить про те, що саме ця закономірність лежить в основі відбору і найменш вивчена Різні ознаки, провідне значення і прогностичність яких встановлені, зібрані разом, є основою для розробки моделі або ідеалу в конкретному виді спорту. Проте спрощений підхід до оцінювання модельних ознак, їх довільний підбір, незведення ознак в модельн характеристики, недостатня обґрунтованість їх взаємозв'язку у майстрів спорту і спортсменів-початківців (часто тільки кореляційний), недоказові дослідження є істотним недоліком більшості експериментальних робіт 3 конкретних питань відбору.

у теорії і практиці відбору є позитивний досвід наукового обґрунтування і використання, поряд 3 руховими показниками, ряду специфічних ознак, що лімітують досягнення високих спортивних результатів спорстменів. Так, в роботах Н. Ж. Булгакової, Т. С. Тімакової $[4,18]$ показано доцільність використання під час відбору плавців широкого комплексу показників, де особливою інформативністю володіють морфофрункціональ- ні ознаки, більшою мірою обумовлені генетично. До числа таких ознак автори відносять довжину тіла й кінцівок, розвиток апарату зовнішнього дихання, рухливість у суглобах, чутливість шкірного аналізатора (рецепторів). Відзначається, що в процесі вікового розвитку має місце індивідуальна мінливість відповідних ознак. Тому під час відбору важливо встановити характер таких змін і передбачити їх подальшу спрямованість.

Слід враховувати і той фракт, що недостатній рівень одного показника у спортсмена часто може компенсуватися гіпертросічним проявом іншого, і це не буде перешкодою для демонстрації високих спортивних результатів. Проте, якщо в процесі тестування з метою визначення перспективних можливостей спортсмена використано обмежену кількість тестів і показ ників, це може привести до неправильного висновку про його потенційні можливості.

Результати досліджень в ряді видів спорту $[3,13,17,54]$ свідчать про те, що ранг дітей за спортивними показниками від року до року змінюється. Багато видатних спортсменів у дитячому віці не відзначалися високими спортивними результатами. I навпаки, багато хто подавав надії в дитинстві, але так і не ставали найсильнішими в старшому віці. Це пояснюється наявністю багатьох фракторів, що лімітують спортивні досягнення, в тому числ морфоорункціональних, ряду фрізіологічних і психофізіологічних. Ці фактори належать до числа найбільш стабільних, мало змінюваних, обумовлених генетично на 70-90 \% [6, 11, 16, 19, 40]. Проте і ці показники можуть бути компенсовані, особливо в дитячому та юнацькому віці, за рахунок досконалої техніки, тактики, підвищених емоцій у ході тестування. Цим і пояснюється думка про доцільність використання на різних етапах відбору спортсменів комплексного оцінювання, включаючи оцінку стану технічної підготовленості і оцінку специфічних здібностей, які зумовлюють досягнення в тому чи іншому виді спорту $[13,23,25]$.

Знання основних фракторів, що визначають вибір спортивної спеціалі- зації, буде неповним для ефективного прогнозування спортивних досягнень без урахування впливів на них спадковості і середовища. Тренувальний процес сприяє визріванню і розкриттю даних природою задатків, перетворення їх у здібності. За наявності яскраво виражених задатків і сприятливих середовищних впливів (перш за все, тренування, виховання, навчання) формується талант. Таким чином, людина - істота біосоціальна, і в ній завжди присутнє біологічне, спадкове, що даровано природою, а також соціальне, що набуте ним самим у процесі діяльності з урахуванням задатків. Причому слід мати на увазі, що ступінь прояву успадкованого і набутого може бути різним, і це є важливим для визначення спортивної придатності.

Для спортивного відбору дітей особливого значення набувають ті 3 основних факторів, що детермінують успішність спортивної діяльності, які більшою мірою лімітовані спадковістю і мають консервативний характер. Це і зрозуміло, оскільки будь-який успішний прогноз можливий лише в тому випадку, якщо в основу його покладені стабільні чинники, які передбачувано розвиваються.

3 генетичної точки зору спортивний талант - явище досить рідкісне. Більшість людей демонструють у спорті результати, близькі до середніх, а осіб, які можуть це робити, так само як і осіб, здатних показати результати, які значно перевищують середні, дуже мало. Спортивний відбір і орієнтація повинні здійснюватися 3 урахуванням головних чинників, що визначають успіх спортивного вдосконалення в конкретному виді спорту, тому що не існує єдиного критерію обдарованості.

Критерії спортивного відбору ґрунтуються на таких теоретичних положеннях:

- обдарованість визначається спадково зумовленими задатками, які стосуються структурних, функціональних і психологічних особливостей, що визначають діяльність і поведінку людини;

- генетично обумовлені задатки характеризуються відносно малою 
мінливістю, що підвищує їх прогностичну цінність. У той самий час тренування і виховання спортсмена сприяють їх своєчасному виявленню та цілеспрямованому вдосконаленню. Таким чином, спадковий фонд фрункціональних можливостей організму може бути розширений у процесі багаторічної підготовки спортсмена за належної організації процесу тренування, особливо у віковий період розвитку;

- показником обдарованості $€$ не тільки абсолютний рівень розвитку тієї чи іншої якості, а й темпи її приросту під впливом факторів зовнішнього середовища, в тому числі завдяки правильній орієнтації тренування;

- на різних етапах спортивного удосконалення змінюється значущість різних властивостей і особливостей морфологічного і функціонального стану спортсмена, що визначають його обдарованість і успіхи спортивного вдосконалення. Тому інформативність окремих критеріїв спортивного відбору і методів його проведення на різних етапах варіює.

Практичний досвід роботи зі спортсменами, наукові дослідження та практична робота в Центрі спортивного відбору, Проблемній науково-дослідній лабораторії високих тренувальних навантажень, науководослідному інституті, багаторічний аналіз та узагальнення даних 3 проблеми пошуку та розвитку спортивного таланту, відбору та подальшої орієнтації спортсменів дозволили окреслити сучасні напрями досліджень 3 проблематики відбору спортсменів. За останні десять років разом з аспірантами та здобувачами виконано ряд досліджень у різних видах спорту та розроблено підходи і технології відбору спортсменів-початківців.

Проведені дослідження [23, 24] дозволили обґрунтувати і розробити сучасну технологію відбору дітей на етапі початкової підготовки у веслуванні на байдарках і каное. Запропонований підхід до розробки педагогічної технології відбору базується на концепції особистісно-орієнтованого навчання й виховання і враховує індивідуальні особливості, вроджені задатки, обдарованість учнів; взаємозв'язку шкільного спорту та спорту вищих досягнень через засвоєння рухових навичок та елементів техніки веслування на байдарках і каное на базі загальноосвітніх шкіл та спеціалізовану підготовку в системі дитячо-юнацьких спортивних шкіл і спортивних клубів. Рекомендована педагогічна технологія відбору дітей на етапі початкової підготовки $з$ веслування на байдарках і каное включає такі складові: організацію груп загальної ффізичної підготовки на базі загальноосвітнього закладу та залучення до занять учнів; тестування, оцінку антропометричних даних та зіставлення паспортного та біологічного віку дитини; розробку програми засвоєння основних елементів техніки веслування на байдарках і каное протягом 18 занять; фрормування критеріїв відбору, тестування, оцінку та визначення перспективних дітей для занять веслуванням на байдарках і каное; відбір здібних дітей до групи початкової підготовки з веслування на байдарках і каное в ДЮСШ, СДЮШОР; навчання основних елементів інших видів спорту дітей, що залишилися в системі шкільного спорту; навчання веслування на байдарках і каное в спеціальних групах початкової підготовки ДЮСШ, СДЮШОР; тестування та відбір під час переходу на другий рік навчання в групах початкової підготовки.

Цю технологію було апробовано та впроваджено в спортивні клуби та відділення з веслування ДЮСШ. Вона дозволила залучити максимальну кількість дітей до занять масовим шкільним спортом, відібрати перспективних дітей до спеціалізованих груп 3 веслування на байдарках і каное. Протягом двох років в експериментальній групі практично не відбулось відсіву (3,5 \% - групи початкової підготовки першого року, 2,5 \% - другого року), що свідчить про стабільність контингенту дітей, які були відібрані через систему шкільного спорту. В контрольній групі наприкінці першого року тренувань відсів становив 28,6 \%, наприкінці другого року - 61,9 \%.

Ряд досліджень присвячено питанню ранньої спеціалізації, набору, відбору та орієнтації підготовки спортсменів у художній гімнастиці. Так, дослідження, проведені спільно з І. С. Сиваш, дозволили обґрунтувати підхід до формування спеціалізації гімнасток - групові вправи - на етапах початкової та попередньої базової підготовки і на цій основі розробити технологію відбору, орієнтації та підготовки спортсменок [26].

Для групових вправ на сьогодні характерним є збільшення обсягу роботи 3 предметом і тілом, що пов'язано зі значною кількістю часу, на їх вдосконалення, відпрацювання елементів обміну, взаємодії та співпраці. Зазначені вище рухові дії є складним координаційним поєднанням рухів окремими ланками тіла з різними предметами. Виконання їх у єдності з музичним супроводом вимагає від спортсменок не тільки значних фрізичних можливостей, а й достатнього рівня розвитку спеціальних рухових якостей, вміння виразно й артистично подати елементи, необхідні для виконання композиції. Правильні технічні рухи, закладені на початкових етапах підготовки, які постійно розвиватимуться і покращуватимуться на наступних етапах, забезпечують зростання майстерності. Навіть найменші відхилення від них призводять до появи значної кількості рухових помилок, які згодом будуть перенесені на більш складні елементи. Тому формування спеціалізації в групових вправах має бути організоване на початкових етапах багаторічного вдосконалення, починаючи з груп початкової підготовки.

Формування спеціалізації «групові вправи» характеризується послідовністю дій, що принципово відрізняється від індивідуальної підготовки в художній гімнастиці, але будується на базі їі школи і не виходить за межі предметно-змістової основи. В основі підходу до формування спеціалізації юних гімнасток у групових вправах на етапах початкової та попередньої базової підготовки є теоретичні знання і практичний досвід художньої гімнастики і суміжних дисциплін. Його елементами, які об'єднують процес формування спеціалізації і створюють перспективи багаторічного вдосконалення гімнасток, $€$ закономірності вікового розвитку і 
початку спеціалізації, показники спортивної орієнтації і відбору з урахуванням вроджених задатків і особливостей спортсменок до виконання групових вправ, засоби і методи спортивної підготовки, критерії та компоненти спеціальної підготовленості. Складовими технології визначено мету та зміст процесу відбору та орієнтації спортсменок у групових вправах для кожного етапу багаторічної підготовки; критерії, показники і нормативні значення; оцінку вихідного і поточних станів підготовленості гімнасток, розробку програми підготовки у групових вправах, відбір спортсменок у групові вправи і подальша орієнтація їхньої підготовки [26].

Дослідження, проведенні за останні п'ять років з А. М. Улан [27], присвячені проблемі визначення фрункціональноїасиметрії у фехтувальниківпочатківців з подальшою орієнтацією їхнього тренувального процесу. Отримані дані дозволили обґрунтувати підходи і розробити алгоритм визначення фрунціональної асиметрії фрехтувальників на початкових етапах багаторічного вдосконалення для побудови індивідуальних профрілів функціональної асиметрії та орієнтації їх підготовки. Нами було встановлено, що у ряді видів спорту та фехтуванні зокрема організація процесу орієнтації підготовки спортсменів повинна ґрунтуватися на вивченні вроджених схильностей спортсменів.

До генетично детермінованих особливостей фахівці відносять функціональну асиметрію, управління якою в процесі підготовки залежно від потреб виду спорту здатне впливати на темпи становлення майстерності спортсмена. 60 \% опитаних вітчизняних та зарубіжних тренерів підкреслили необхідність урахування функціональної асиметрії в процесі орієнтації спортивної підготовки фехтувальників. $50 \%$ респондентів відзначили як найбільш значущу моторну асиметрію верхніх та нижніх кінцівок та $54 \%$ необхідність визначення фрункціональної асиметрії вже на початковому етапі підготовки. Статистичний аналіз кількості фехтувальників 3 мануальною асиметрією на міжнародній арені дозволив виявити тенденцію до збіль- шення кількості ліворуких спортсменів за останні 10 років та їх високу результативність на світовій арені.

Нами було визначено п'ять підходів, які застосовують тренери на практиці для раціонального використання функціональної асиметрії в окремих видах спорту: нівелювання асиметрії, акцентування асиметрії, формування перехресної асиметрії, невраховування асиметрії, переучування спортсменів. Під час розробки підходу для визначення функціональної асиметрії фехтувальників-початківців ми орієнтувалися на вираженість асиметрії 3 перерозподілом навантаження на непровідну сторону та формування перехресної асиметрії. При цьому вибір підходу залежить від виявленого індивідуального профілю асиметрії (ІПА) спортсмена. Ми враховували що у фехтуванні, навіть під час визначення у спортсмена провідної лівої (правої) ноги, стійка буде визначатись рукою, яка $є$ домінуючою. Результати досліджень дозволили побудувати 17 профрілів асиметрії за комбінацією «рука-нога-око-вухо», систематизувати загальні та спеціальні тести для визначення індивідуального профрілю функціональної асиметрії початківців у фехтуванні та розробити алгоритм визначення функціональної асиметрії фехтувальників на початкових етапах багаторічного вдосконалення. В ході апробації даного алгоритму було визначено ІПА 20 спортсменів, підходи до орієнтації підготовки юних феетувальників, надано рекомендації тренеру та проведено контроль через рік занять спортом [27].

Цікавим напрямом досліджень проблем відбору та орієнтації підготовки спортсменів $є$ відбір спортсменів у команду (екіпаж) та фрормування команд. Такі дослідження було проведено в баскетболі спільно з М. М. Безмиловим [2] та в академічному веслуванні з 0. О. Яковенко [28].

Від ефективності комплектування команди безпосередньо залежить спортивний результат, який досягається спільними зусиллями партнерів по команді. Поряд 3 індивідуальними можливостями гравців на відбір в команду впливають обраний тактичний варіант, особливості тактики і тех- ніки команди суперника. Важливим $є$ і вміння кожного гравця реально оцінювати можливості свої і партнерів, підпорядковувати прагнення до досягнення особистого успіху інтересам команди. Під час комплектування команди необхідно орієнтуватися на те, наскільки можливості окремих гравців відповідають їхнім ігровим амплуа в команді, характеру покладених на них функцій і завдань.. Формування комплексної системи оцінки баскетболістів різного рівня та ігрового амплуа, морфоофункціональних даних та моделей підготовленості гравців за ігровими амплуата дозволила виявити перспективних сопртсменів та формувати команду з урахуванням суперника та рівня підготовленості і досвіду гравців [2].

У веслуванні академічному спільно з 0. О. Яковенко [28] було сформовано підхід до комплектування екіпажів та розроблено алгоритм відбору спортсменів у командні човни, що дозволило підвищити процес підготовки та ефективність змагальної діяльності. Академічне веслування як технічно складний вид спорту вимагає точної координації в роботі майже усіх м'язових груп спортсменів. Командна техніка веслування характеризується одночасністю дій всіх спортсменів, де вони включені в єдину систему рухів, і надзвичайно важко оцінити ефективність діяльності одного веслувальника ізольовано від команди. Під час фрормування екіпажу необхідно враховувати, що веслувальник знаходиться в системі соціальних зв'язків; він може бути вираженим одиночником або командним спортсменом (відмінності в техніці командної і одиночної техніки веслування, у вимогах до фрізичної і моральновольової підготовки тощо). Під час комплектування командних човнів необхідно спиратися на етапи відбору, критерії, особливості розсадження; відмінності в організації, змісті і методиці навчально-тренувальної роботи в командних екіпажах

Алгоритм відбору характеризувався етапністю заходів, містить організаційні та методичні складові, систему тестів, а також критерії та оціночні шкали. 3 метою ефективності відбо- 
ру спортсменів до складу екіпажу запропоновані заходи проводили чотири рази за сезон. Це дало можливість тренеру вибрати групу веслувальників і сорормувати базові екіпажі: один великий (4' або 8+) і кілька дрібних (1' або 2). Відбір спортсменів і комплектування екіпажів здійснювали за трьома категоріями веслувальників, що виконують різні фрункції в човні і мають характерні відмінності й особливості за антропометричними, фрункціональними, біомеханічними і педагогічними показниками: загребний; 2-3-й номери в четвірках і 2-7-й номери у вісімках; 1-й номер [28].

Дискусія. Проведені фахівцями дослідження з питань пошуку та визначення талантів у різних сорерах людської діяльності дозволяють стверджувати, що більшість дослідників згодні, що спадкові чинники є вирішальними для прояву екстраординарних здібностей і майстерності, які можна визначити як талант. В. Б. Іссурін [8] зазначає, що прихильники природного таланту не відкидають необхідність і важливість цілеспрямованого виховання і навчання, високоспеціалізованої практики і багаторічних тренувань. 3 іншого боку, прихильники чинників навколишнього середовища у феномені таланту не завжди визнають роль вроджених рис в досягненні справжньої досконалості в певній галузі. Ці загальні положення і протилежні думки, безумовно, впливають на розуміння поточної ситуації в спортивній науці і спортивній практиці.

Проте певна специфіка й унікальність спортивних реалій дає суттєву перевагу в розпізнаванні й остаточній ідентифрікації таланту. Змагальна діяльність, притаманна спорту, і наявність об'єктивних показників майстерності дозволяють науковцям та фахівцям визначати талановиту особистість на основі її досягнень і рекордів у світовому спорті.

Серйозні дослідження цього питання було розпочато на початку 1970-х років. Найбільш передовими країнами у виявленні та пошуку талантів фахівці визначають країни Східної Європи, передовсім НДР, методологічне обґрунтування та розробка сис- теми відбору були зроблені в СРСР. У країнах Західної Європи і США також проводилися перспективні дослідження. 3 початку 1990-х років досвід колишніх соціалістичних країн став доступним для міжнародних експертів і аналітиків у сфері спорту. В результаті було успішно реалізовано ряд проєктів 3 «пошуку талантів» в Австралії, Канаді, Великій Британії, США, Нідерландах, Бельгії, Німеччині і Швейцарії. Прогрес китайських спортсменів-олімпійців був обумовлений застосуванням строго структурованої системи пошуку і розвитку талантів від рівня школи до національних олімпійських центрів і національних збірних команд [8, 9,13, 31, 45, 47, 56].

Фахівці сходяться на думці, що визначити індивідуальну схильність до спортивних досягнень шляхом будьяких одноразових процедур (спостереження, тестування тощо) за короткий час неможливо $[7,17,56]$. Це пояснюється тим, що спортивна схильність - багатоскладовий комплекс індивідуальних властивостей, ряд яких проявляється не одночасно, а гетерохронно залежно від віку і стажу спортивної діяльності. Індивідуальні можливості спортивних досягнень і особистісні установки на їх реалізацію динамічні, змінюються як через природні особливості індивідуального розвитку, так і під впливом соціальних умов життя. Таким чином, діагностику індивідуальної спортивної схильності та спортивну орієнтацію необхідно здійснювати як поетапно поновлюваний процес. Закономірності побудови оптимальної системи підготовки спортсмена зобов'язують у межах початкового етапу забезпечувати первинну спортивну орієнтацію й уточнювати її під час завершення цього етапу 3 відносно жорстким вибором предмета поглибленої спортивної спеціалізації, напрямами та параметрами подальшої спортивної діяльності. Можна сказати, що з початку систематичної спортивної діяльності в дитячому та підлітковому віці у багатьох випадках буває достатньо двох-трьох років, щоб у першому наближенні коректно визначити доцільний напрям спортивної спеціалізації і спрогнозувати спор- тивні перспективи. Проте ця первинна орієнтація в подальшому підлягає більш істотним корекціям, особливо коли в реальних умовах життя спортсмену потрібно буде вирішувати: йти в сфреру спорту вищих досягнень чи обмежитися сферою масового спорту $[13,14]$.

Формування сучасного погляду на систему відбору та орієнтації підготовки спортсменів необхідно будувати, враховуючи положення, пов'язані 3 організаційними та методичними основами. Формування організаційних основ сучасної системи підготовки спортсменів вимагає сьогодні досить тісного зв'язку з етапами багаторічного вдосконалення, з рівнем майстерності спортсменів. Це можливо здійснити шляхом взаємодії всіх ланок дитячо-юнацького спорту та спорту вищих досягнень 3 метою створення умов для формування перспективного резерву через залучення найбільш обдарованих дітей зі спортивних шкіл, училищ, ліцеїв до централізованої підготовки. Під час вирішення питань оптимізації організаційної структури системи багаторічного вдосконалення необхідно враховувати рівнозначний розподіл уваги до матеріальнотехнічного, фрінансового, кадрового, науково-методичного та медичного забезпечення на всіх етапах підготовки спортсменів. Це дозволить ефективно працювати одночасно як зі спортсменами найближчого і віддаленого резерву, так і зі спортсменами збірних команд України з видів спорту [20, 21, 22, 23].

Отримані в процесі досліджень дані підтвердили, що оцінювання обдарованості і перспективності спортсмена з метою визначення його потенційних можливостей має на увазі використання широкого кола показників, які в цілому охопили б усі сторони підготовленості, що визначають спортивний результат. Фахівці рекомендують орієнтуватися перш за все на консервативні, генетично обумовлені ознаки обдарованості. Це твердження не можна визнати справедливим, оскільки коло таких показників досить обмежене, і якщо в процесі відбору використовувати тільки їх, то це значно звузить коло оцінюваних 
здібностей спортсмена. Таким чином, комплексний розгляд питання відбору обдарованих спортсменів доцільно здійснювати за рахунок включення в число оцінюваних параметрів й ті, які змінюються з року в рік. Правильність і об'єктивність оцінки можуть бути досягнуті при використанні показників інформативних для конкретного віку.

Проведені дослідження дозволили підтвердити ряд положень даної проблеми: відбір і орієнтація спортсмена повинні здійснюватися в процесі багаторічної підготовки систематично, багатоступінчасто, що пов'язано з високою надійністю прогнозів у дитячому віці по відношенню до спортивних досягнень цих самих спортсменів у старшому віці [4]; незалежно від кількості ступенів відбору система тестування повинна відповідати цілям і завданням тренування на відповідному етапі багаторічної підготовки спортсменів $[5,13,14,23,56]$; використання комплексного підходу в процесі відбору та орієнтації підготовки спортсменів 3 урахуванням різних сторін оцінювання можливостей атлетів дозволяє підвищити об'єктивність висновків і рекомендацій 3 можливостей спортсменів [13, 20, 30, 47].

Під час вибору критеріїв спортивного відбору необхідно враховувати, що обдарованість визначається спадково зумовленими задатками, які стосуються структурних, функціональних і психологічних особливостей, що визначають діяльність і поведінку індивідуума. Генетично обумовлені задатки характеризуються малою мінливістю, що підвищує їх прогностичну цінність, тоді як тренування і весь процес спортивної підготовки сприяють їх своєчасному виявленню та цілеспрямованому вдосконаленню. Таким чином, спадковий фонд функціональних можливостей організму може бути розширений у процесі багаторічної підготовки спортсмена за належної організації процесу тренування, особливо у віковій період розвитку. Показником обдарованості є не тільки абсолютний рівень розвитку тієї чи іншого якості, а й темпи приросту його під впливом фракторів зовнішнього середовища, в тому числі завдяки правильно зорієнтованим тренуванням.
Підтверджено, що на різних етапах спортивного удосконалення змінюється значущість різних властивостей і особливостей морфологічного і функціонального стану спортсмена, що визначають його обдарованість перспективність спортивного вдосконалення. Тому інформативність окремих критеріїв спортивного відбору методів його проведення на різних етапах варіюють. Вирішення цієї проблеми можливе при комплексному підході, що дозволяє всебічно оцінити рухові можливості спортсменів з урахуванням соціальних факторів, педагогічних і медико-біологічних показників, що характеризують стан рухової функції і особливості протікання психічних процесів.

Висновки. Сформульовані основн положення, що становлять систему знань про пошук та розвиток спортивного таланту, відбір та спортивну орієнтацію як єдиного цілого, ґрунтуються на необхідності тривалої підготовки до досягнення високого спортивного результату, урахування закономірностей спортивного відбору і напрямів орієнтації тренувального процесу для підвищення його ефективності, створення організаційних і методичних умов для ефективного індивідуального розвитку виявлених спортивно обдарованих дітей та ефективної реалізації їхніх можливостей у змагальній спортивній діяльності, орієнтованій на максимальні досягнення.

Конфлікт інтересів. Автор заявляє, що відсутній будь-який конфлікт інтересів.

\section{ЛІТЕРАТУРА}

1. Бальсевич ВК. Спортивный талант: генезис, выявление, развитие, реализация. Соврем. олимп. спорт: тез. докл. Киев. 1997; 238-9.

2. Безмылов Н, Шинкарук О, Мурзин Е. Система отбора игроков и подготовка резерва для национальной сборной команды по баскетболу. Спортивний вісник Придніпров'я. 2016; 1: 5-14.

3. Бриль МС. Отбор в спортивных играх Москва: Физкультура и спорт. 1980; 128 с.

4. Булгакова НЖ. Спортивные способности: диагностика и формирование. Теория и практи ка фриз. культуры. 2009; 9: 49-51.

5. Волков ВМ, Филин ВП. Спортивный отбор. Москва: Физкультура и спорт. 1983; 176 с.

6. Губа ВП. Основы распознания раннего спортивного таланта: учеб. пособие для вузов физ. культуры. Москва: Терра-Спорт. 2003 $208 \mathrm{c}$.

7. Давыдов ВЮ. Теоретические основы спортивного отбора и специализации в олим- пийских водных видах спорта дистанционного характера [автореферат]. Москва. 2002; 40 с.

8. Иссурин ВБ. Спортивный талант: прогноз и реализация. 2017; 3-47

9. Майснер-Петиг Д, Корт Д, Шобер Х. Некоторые аспекты разработки критериев спортивной пригодности по показателям быстроты и скоростно-силовых способностей. Теоретические и методические аспекты проблемы отбора в спорте. Москва. 1990; 10-22.

10. Мотылянская PE, Налбандян МА. Новые методические подходы к выявлению генетически обусловленных параметров в системе спортивного отбора. Теория и практика физ. культуры. 1984; 12: 24-5.

11. Никитюк ВА. Генетические маркеры и их роль в спортивном отборе. Теория и практика физ. культуры. 1985; 11: 38-40.

12. Озолин Н. Современная система спортивной тренировки. Москва: Физкультура и спорт. 1970; 479 с

13. Платонов ВН. Система подготовки спортсменов в олимпийском спорте. Общая теория и ее практические приложения: учебник [для тренеров]: в 2 кн. Киев: Олимпийская лит., Кн. 2., 2015; 752 c.

14. Сахновский КП. Теоретико-методические основы системы многолетней спортивной подготовки [дисертация]. Киев. 1997; 318 с.

15. Селуянов ВН, Шестаков МП. Определение одаренностей и поиск талантов в спорте. Москва: СпортАкадемПресс. 2000;112 с.

16. Сергиенко ЛП. Генетика двигательных способностей: состояние изучения проблемы и перспективы. Наука в олимпийском спорте: спец. вып. 1999; 78-87.

17. Сирис ПЗ, Гайдарска ПМ, Рачев КИ. Отбор и прогнозирование способностей в легкой атлетике. Москва: Физкультура и спорт. 1983; $103 \mathrm{c}$.

18. Тимакова Т. Спортивный отбор: объективные и субъективные аспекты. Wychowanie fizychne i sport. 2002; Vol. XLVI (1): 343-4.

19. Шварц ВБ, Хрущев СВ. Медико-биологические аспекты спортивной ориентации и отбора. Москва: Физкультура и спорт. 1984; 151 с.

20. Шинкарук 0. Узагальнення досвіду організації відбору в олімпійському спорті. Теорія і методика фрізичного виховання і спорту. 2001; 2-3: 35-9.

21. Шинкарук 0. Особливості організації відбору спортсменів у циклічних видах спорту. Теорія і методика фрізичного виховання і спорту. 2002; 1: 34-42.

22. Шинкарук 0. Обґрунтування використання фрізіологічних показників як критеріїв відбору спортсменів у циклічних видах спорту. Актуальні проблеми ффізичної культури і спорту: зб. наук. пр. Київ: ДНДІФКС. 2004; 3: 52-5.

23. Шинкарук ОА. Отбор спортсменов и ориентация их подготовки в процессе многолетнего совершенствования (на материале олимпийских видов спорта). Киев: Олимпийская лит. 2011; 360 с.

24. Шинкарук 0, Матвієнко І. Обґрунтування та розробка педагогічних технологій відбору на етапі початкової підготовки у веслуванні на байдарках і каное. Теорія і методика фрізичного виховання і спорту. 2010; 2: 48-51.

25. Шинкарук 0, Мітова О. Система контролю підготовки початківців у командних спортивних іграх: проблемні питання та сучасні підходи. Спортивний вісник Придніпров'я. 2017; 1:105-112.

26. Шинкарук ОА, Сиваш ИС. Художественная гимнастика: отбор и ориентация подготов- 
ки спортсменок в групповых упражнениях: Мо нография. Киев, Олимпийская лит. 2016; 120 с

27. Шинкарук 0, Улан А. Современные представления 0 функциональной ассиметрии у мужчин и женщин в спорте (на примере фехтования). Спортивна медицина і фізична реабілітація. 2018; 1:15-23.

28. Шинкарук ОА, Яковенко О0. Обґрунтування підходу до формування екіпажів у веслуванні академічному. Теорія і методика фізичного виховання і спорту. 2014; 4: 23-7.

29. Anshel MH, Lidor R. Talent detection in sport: The questionable use of psychological testing. Journal of Sport Behavior; 2012; 3: 239-266.

30. Arnot R, Gaines C. Tratado de la actividad fisica: Seleccione su deporte. Barcelona: Paido tribo. 1992; 453 p

31. Brown J. Sport talent. Champaign, Ili Human Kinetics, 2001; 300 p

32. Byshevets N, Denysova L, Shynkaruk 0 Serhiyenko K, Usychenko V, Stepanenko 0 Syvash I. Using the methods of mathematical statistics in sports and educational research. Journa of Physical Education and Sport, 2019; 19 (3), Art 148, pp. 1030-4

33. Carroll JB. Human cognitive abilities: A survey of factor-analytic studies. Cambridge, UK Cambridge University Press. 1993; 820 p.

34. Ericsson KA. The scientific study of expert levels of performance: General implications for optimal learning and creativity. High Ability Studies 1998; 9: 75-100.

35. Ericsson KA, Krampe RTh \& Tesch Romer $\mathrm{C}$. The role of deliberate practice in the acquisition of expert performance. Psychological Review; 1993; 100: 363-406.

36. Eysenck HJ. Genius: The natural history of creativity. Cambridge University Press. 1995; 148-74

37. Ford P, De Ste Croix M, Lloyd R et al. The long-term athlete development model. Physiological evidence and application. J Sport Sci; 2011; 29(4): 389-402.

38. Gagne F. Constructs and models pertaining to exceptional human abilities. In: International handbook of research and development of giftedness and talent. In: K.A. Heller, F.J. Mönks \& A.H. Passow (Editors). Pergamon Press. 1993; p 69-87.

39. Gagné F. From gifts to talents: The DMGT as a developmental model. In R.J. Sternberg \& J.E. Davidson (Editors), Conceptions of giftedness (2nd ed., pp. 98-120). Cambridge, UK: Cambridge University Press. 2005; 467 p.

40. Gaisl G. Genetisce Komponent des Sporttalents. Leistungssport. 1980; Vol. 10 (2)

41. Gardner H. Intelligence reframed: Multiple Intelligences for the 21st century. New York: Basic Books. 1999

42. Gustin WC. The development of exceptional research mathematicians. In: Bloom, B.S (editor). Developing talent in young people. Ballantine. 1985

43. Harre D. Principles of sport training. Berlin: Sportverlag. 1982

44. Hohman A, Seidel L. Scientific aspect of talent development. Journal of Physical Education; 2003; 40(1): 9-20

45. Howe M, Davidson J, Sloboda J. Innate talents: Reality or myth? Behavioral and Brain Sciences; 1998; 21(3): 339-407.

46. Jinri Jiang MS. How to select potential Olympic swimmers. American swimming magazine. 1993; 14-8.

47. Klaus A. Erfahrungen bei der talentforderung und auswahl am beispill der leicht-atletic.
Talenterkennung und forderung im sport. Leipzig 1991; 108-18.

48. Lidor R, Côté J, Hackfort D. ISSP position stand: to test or not to test? The use of physica skill tests in talent detection and in early phases of sport development. Intern J Sport Exerc Psychol; 2009; 7(2): 131-46.

49. Manturzewska M. Musical talent in the light of biographical research. In: Musikalische Begabung finden und förden. Bosse. 1986.

50. Mishchenko V, Shynkaruk 0, Suchanows ki A. et al. Individualities of Cardiorespiratory Responsiveness to Shifts in Respiratory Homeostasis and Physical Exercise in Homogeneous Groups of High Performance athletes. Baltic J. Health Phys. Activity. 2010; 1: 13-29.

51. Simonton DK. Talent and its development: an emergenic and epigenetic model. Psychologica Review; 1999; 106 (3): 435-457.

52. Sloan KD., Sosniak LA. The development of accomplished sculptors. In: Developing talent in young people, ed. B.S. Bloom. Ballantine. 1985

52. Sloboda JA, Davidson JW, Howe MJA et al. The role of practice in the development of per forming musicians. British Journal of Psychology; 1996; 87: 287-309

54. Stroganov S, Serhiyenko K, Shynkaruk O Byshevets N, Denysova L, Yukhno Yu, Stepanenko 0 , Ulan A. Features of preventive activity at the initial stage of training of many years standing of young basketball players. Journal of Physical Education and Sport. 2020; Vol 20 (1), Art 66: 452 - 5 DOI:10.7752/jpes.2020.s1066

55. Tesch-Romer C. Attributed talent is a po werful myth. Behavioral and Brain Sciences. 1998 21 (3): 427

56. Zaporozhanov V, Sozanski H. Dobor kwalifikacja do sportu, Warszawa, 1997; 5-14.

\section{LITERATURE}

1. Balsevich VK. Sports talent: genesis, identification, development, realization. Modern Olympic Sport: reports theses. Kiev. 1997; 238-9.

2. Bezmylov N, Shinkaruk 0, Murzin E. The system of selection of players and preparation of the reserve for the national basketball team. Spor tyvnyi visnyk Prydniprovia. 2016; 1: 5-14.

3. Bril MS. Selection in sports games Moscow: Fizkultura i sport . 1980; 128 p.

4. Bulgakova NZ. Athletic abilities: diagnosis and formation. Teoriya i praktika fizicheskoy kul tury. 2009; 9: 49-51.

5. Volkov VM, Filin VP. Sports selection Moscow: Fizkultura i sport. 1983; 176 p.

6. Guba VP. Fundamentals of early sports talent recognition: teaching guide for phys. culture institutions. Moscow: Terra-Sport. 2003; 208 p.

7. Davydov VY. Theoretical foundations of sports selection and specialization in the Olympic distance water sports events [abstract]. Moscow. 2002; 40 p.

8. Issurin VB. Sports talent: forecast and realization. 2017; 3-47

9. Meisner-Petig D, Court D, Schober H. Some aspects of the development of criteria for sports suitability in terms of speed and speed-strength abilities. Theoretical and methodological aspects of the problem of selection in sport. Moscow. 1990; 10-22.

10. Motylyanskaya RE, Nalbandyan MA New methodological approaches to identifying genetically determined parameters in the system of sports selection. Teoriya i praktika fizicheskoy kultury. 1984; 12: 24-5.
11. Nikityuk VA. Genetic markers and their role in sports selection. Teoriya i praktika fiziches koy kultury. 1985; 11: 38-40.

12. Ozolin N. Modern system of sports training. Moscow: Fizkultura i sport. 1970; 4793.

13. Platonov VN. System of athletes' preparation in the Olympic sport. General theory and its practical applications: textbook in 2 b. Kiev: Olimpiyskaya literatura, Book 2, 2015; 752 p.

14. Sakhnovsky KP. Theoretico-methodical bases of the system of long-term sports preparation [dissertation]. Kiev. 1997; 318 p.

15. Seluyanov VN, Shestakov MP. Identifying giftedness and finding talents in sports. Moscow: SportAkademPress. 2000;112 p.

16. Sergienko LP. Genetics of motor abilities the state of the study of the problem and prospects. Nauka v Olimpiyskom sporte. 1999; 78-87.

17. Siris PZ, Gaidarska PM, Rachev KI Selecting and predicting abilities in athletics. Moscow: Fizkultura i sport. 1983; 103 p.

18. Timakova T. Sports selection: objective and subjective aspects. Wychowanie fizychne sport. 2002; Vol. XLVI (1): 343-4.

19. Schwartz VB, Khrushchev SV. Medicobiological aspects of sports orientation and selection. Moscow: Fizkultura i sport. 1984; 151 p

20. Shynkaruk 0. Generalization of the experience of organizing selection in Olympic sports. Teoriia i metodyka fizvykhovannia i sportu. 2001; 2-3: 35-9.

21. Shynkaruk 0 . Features of the organization of athlete selection in cyclic sports events. Teo riia i metodyka fizvykhovannia i sportu. 2002; 1 34-42.

22. Shynkaruk 0. Substantiating the use of physiological indices as criteria for athlete selection in cyclic sports events. Actual problems of physical culture and sport: coll. sci. pap. Kyiv SSRIPCS. 2004; 3: 52-5.

23. Shinkaruk $O A$. The selection of athletes and the orientation of their training in the process of long-term improvement (based on the materia of the Olympic sports events). Kiev: Olimpiyskaya literatura. 2011; $360 p$

24. Shynkaruk 0, Matvienko I. Substantiation and development of pedagogical selection technologies at the stage of initial training in kayaking and canoeing. Teoriia i metodyka fizvykhovannia sportu. 2010; 2: 48-51.

25. Shynkaruk 0, Mitova 0 . The system of control of preparation of beginners in team sports games: problem questions and modern approaches. Sportyvnyi visnyk Prydniprovia. 2017 1:105-112.

26. Shinkaruk OA, Sivash IS. Rhythmic gymnastics: selection and orientation of the training of female athletes in group exercises: Monograph. Kiev: Olimpiyskaya literatura. 2016 $120 \mathrm{p}$

27. Shinkaruk 0, Ulan A. Modern concepts of functional asymmetry in men and women in sports (on the example of fencing). Sportyvna medytsyna i fizychna reabilitatsia. 2018; 1:15-23.

28. Shynkaruk OA, Yakovenko 00. Substantiation of the approach to the formation of crews in academic rowing. Teoriia i metodyka fizvykhovannia i sportu. 2014; 4: 23-7.

29. Anshel MH, Lidor R. Talent detection in sport: The questionable use of psychological testing. Journal of Sport Behavior; 2012; 3: 239-266.

30. Arnot R, Gaines C. Tratado de la actividad fisica: Seleccione su deporte. Barcelona: Paido tribo. 1992; 453 p.

31. Brown J. Sport talent. Champaign, Ili Human Kinetics, 2001; 300 p. 
32. Byshevets N, Denysova L, Shynkaruk 0, Serhiyenko K, Usychenko V, Stepanenko 0, Syvash I. Using the methods of mathematical statistics in sports and educational research. Journal of Physical Education and Sport, 2019; 19 (3), Art 148, pp. 1030-4

33. Carroll JB. Human cognitive abilities: A survey of factor-analytic studies. Cambridge, UK: Cambridge University Press. 1993; 820 p.

34. Ericsson KA. The scientific study of expert levels of performance: General implications for optimal learning and creativity. High Ability Studies; 1998; 9: 75-100.

35. Ericsson KA, Krampe RTh \& TeschRomer $\mathrm{C}$. The role of deliberate practice in the acquisition of expert performance. Psychological Review; 1993; 100: 363-406.

36. Eysenck HJ. Genius: The natural history of creativity. Cambridge University Press. 1995 148-74

37. Ford P, De Ste Croix M, Lloyd R et al. The long-term athlete development model. Physiological evidence and application. J Sport Sci; 2011; 29(4): 389-402.

38. Gagne F. Constructs and models pertaining to exceptional human abilities. In: International handbook of research and development of giftedness and talent. In: K.A. Heller, F.J. Mönks

\section{ІНФОРМАЦІЯ ПРО АВТОРА}

Шинкарук Оксана Анатоліївна http://orcid.org/0000-0002-1164-9054, E-mail: shi-oksana@ukr. net

Національний університет фізичного виховання і спорту України, вул. Фізкультури 1, м. Київ, 03150, Україна

\section{INFORMATION ABOUT THE AUTHOR}

Shynkaruk Oksana http://orcid.org/0000-0002-1164-9054, E-mail: shi-oksana@ukr.net National University of Ukraine on Physical Education and Sport: Fizkul'tury str. 1, Kyiv, 03150, Ukraine
47. Klaus A. Erfahrungen bei der talentforderung und auswahl am beispill der leicht-atletic. Talenterkennung und forderung im sport. Leipzig, 1991; 108-18.

48. Lidor R, Côté J, Hackfort D. ISSP position stand: to test or not to test? The use of physical skill tests in talent detection and in early phases of sport development. Intern J Sport Exerc Psychol; 2009; 7(2): 131-46.

49. Manturzewska M. Musical talent in the light of biographical research. In: Musikalische Begabung finden und förden. Bosse. 1986.

50. Mishchenko V, Shynkaruk 0, Suchanowski A et al. Individualities of Cardiorespiratory Responsiveness to Shifts in Respiratory Homeostasis and Physical Exercise in Homogeneous Groups of High Performance athletes. Baltic J. Health Phys. Activity. 2010; 1: 13-29.

51. Simonton DK. Talent and its development: an emergenic and epigenetic model. Psychological Review; 1999; 106 (3): 435-457.

52. Sloan KD., Sosniak LA. The development of accomplished sculptors. In: Developing talent in young people, ed. B.S. Bloom. Ballantine. 1985.

52. Sloboda JA, Davidson JW, Howe MJA et al. The role of practice in the development of performing musicians. British Journal of Psychology; 1996; 87: 287-309.

54. Stroganov S, Serhiyenko K, Shynkaruk 0, Byshevets N, Denysova L, Yukhno Yu, Stepanenko 0 , Ulan A. Features of preventive activity at the initial stage of training of many years standing of young basketball players. Journal of Physical Education and Sport. 2020; Vol 20 (1), Art 66: 452 - 5. DOI:10.7752/jpes.2020.s1066

55. Tesch-Romer C. Attributed talent is a powerful myth. Behavioral and Brain Sciences. 1998; 21 (3): 427.

56. Zaporozhanov V, Sozanski H. Dobor i kwalifikacja do sportu, Warszawa, 1997; 5-14.

Надійшла 18.03.2020 